\title{
Effect of Different Plant Growth Regulators on In-vitro Callus Induction in Carica papaya (cv. Pusa Nanha)
}

\author{
Nisha Malik ${ }^{1 *}$, Rakesh Singh Sengar ${ }^{1}$, Manoj Kumar Yadav ${ }^{1}$, Shiv Kumar Singh ${ }^{2}$, \\ Gopal Singh ${ }^{3}$ and Mukesh Kumar ${ }^{4}$
}

${ }^{1}$ Department of Agricultural Biotechnology, ${ }^{2}$ Department of Genetics and Plant Breeding, ${ }^{3}$ Department of Plant Pathology, ${ }^{4}$ Department of Horticulture, College of Horticulture, S.V.P.U.A. \&T., Meerut- 250110 (U.P.), India

*Corresponding author

\section{A B S T R A C T}

The present investigation was conducted to optimize an efficient callus induction protocol in Carica papaya (cv. Pusa Nanha). Two different types of explants were collected from field grown papaya plants under study viz., leaf and petiole. The

Keywords

Papaya, Callus, NAA, Kinetin, TDZ

Article Info

Accepted:

10 June 2019 Available Online: 10 July 2019 explants were surface sterilized and excised into 1-2 cm diameter and inoculated on basal MS medium supplemented with various concentrations of NAA, Kinetin and TDZ. The cultures were kept in dark inside the culture room at $25 \pm 2{ }^{\circ} \mathrm{C}$ and humidity $60-65 \%$. The results obtained under study indicate that media containing only NAA and Kinetin results in less percent of callus induction in both explants (11.33 to $30 \%$ in leaf and 3.66 to $7 \%$ in petiole) whereas earliest and significantly ( $p<0.05$ ) higher callus induction was obtained in media containing $3.0 \mathrm{mg} / \mathrm{L} \mathrm{NAA}$ $+0.5 \mathrm{mg} / \mathrm{L}$ Kin and $1.5 \mu \mathrm{M}$ TDZ. Callus produced from leaf was soft and spongy and white in colour while petiole produced hard and friable callus appeared dark in colour. The findings of study suggesting leaf as the best explant and TDZ as an effective growth regulator for callus production in papaya. This protocol for callus induction may also help in propagating papaya plants via somatic embryogenesis, organogenesis and transformation studies.

\section{Introduction}

Papaya (Carica papaya L.) is an economically important fruit crop grown in tropical and subtropical regions of the world (Jaime et al., 2007). It is a single-stemmed, semi-woody, latex-producing, short lived perennial herb, belongs to a small family caricaceae having six genera in the world. The genus carica L. is represented by four species in India, of which Carica papaya $\mathrm{L}$. is the most widely cultivated and the best-known species (Jean et al., 2011; Vij and Prashar 2015). Due to its high yield, nutritional value and year-round fruit production, the importance of this crop around the world is undeniable. It is a 
polygamous species having three sex types; male, female and hermaphrodite (Bhattacharya and Khuspe, 2001). The small genome size of papaya (372 Mbp) and the fact that it can produce fruit in as few as 9 months make it a potential model organism for fruitproducing tree crops (Ming et al., 2001). Papaya is cultivated in about 71 countries of the world over an area of about 440,629 ha, producing 13,016,281 tonnes of papaya with an average productivity of $2.95 \mathrm{lakh} \mathrm{hg} / \mathrm{ha}$ (FAOSTAT 2017). India is the major papaya producing country with respect to area (134000 ha), yield (443284 hg/ha) and production (5940000 tonnes) followed by Brazil, Mexico and Indonesia (FAOSTAT, 2017).

Papaya is conventionally propagated through seeds (Fernando et al., 2001) but the set back of propagating by seed is the production of non true-to-type planting materials (Panjaitan et al., 2007; Tsai et al., 2009) due to segregation of offsprings at second filial generation that leads to inherent heterozygosity (Veerannale 1984; Rajeevan and Pandey 1986).

Asexual propagation methods (cutting and grafting) are also very tedious and impractical when carried out on a large scale (Saker et al., 1999). Now days, tissue culture techniques has been established as an efficient method for production of true-to-type and disease free plantlets and can be used as reliable strategy.

The in-vitro propagation, plantlets produced in two ways either through emergence of adventitious organs directly from explants intervening callus phase or organogenesis through callus formation with de novo origin. Many studies have been reported on callus induction from hypocotyls (Fitch 1993), lamina and midrib explants (Prahardini and Sudaryono 1992), ovules (Rojas and Kitto 1991), shoot tips (Yang and Ye 1992) and petiole (Mosella and Iligarray 1985), root, stem and leaf segments from in vitro grown seedlings (Mondal et al., 1994), buds (Jordan and Velozo, 1995), suspension cultures (Ye et al., 1993). Callus induction from explants requires the presence of appropriate concentrations and combinations of plant growth regulators in the culture media. It is well known that different growth hormones, nutrients, culture conditions and explants play an important role in the growth of plant tissue cultures. Present study was designed to optimize an efficient and rapid callus induction protocol from mature plant Carica papaya. This optimization study might be helpful in generating somatic embryogenesis and subsequent organogenesis from the explant derived callus.

\section{Materials and Methods}

\section{Plant source and material}

The present study was carried out at Tissue Culture Laboratory, Department of Agricultural Biotechnology, College of Agriculture, SVPUA\&T, Meerut, UP, India. Plant material for this research was leaves and petiole of Carica papaya L. (cv. Pusa Nanha) collected from field grown mature female plants.

\section{Surface sterilization of explants}

Initially the explants were thoroughly washed under running tap water for 15-20 minutes. Explants were surface disinfested by 2-3 drops of Tween-20 as surfactant for 15-20 minutes following surface sterilization under laminar air flow hood by $0.1 \%$ bavistin for 10 minutes. They were then treated in $4 \% \mathrm{NaOCl}$ for $2-3$ minutes after that $0.1 \%$ mercuric chloride was used for 2 minutes followed by 3 washings with autoclaved distilled water after each treatment. 


\section{Media preparation}

In present investigation, MS medium (Murashige and Skoog, 1962) was used with various combinations of growth hormones. The $\mathrm{pH}$ of the medium was adjusted to $5.8 \pm$ 0.01 . While recording the $\mathrm{pH}$, medium was continuously stirred using a magnetic stirrer to attain uniformity of $\mathrm{pH}$. Agar powder $(8 \mathrm{~g} / \mathrm{L})$ was then added to the media as solidifying agent. The culture media was then subjected to autoclaving at $121^{\circ} \mathrm{C}$ and $15 \mathrm{lbs}(101 \mathrm{kpa})$ for 20 minutes before 3 days of inoculation.

\section{Callus initiation and proliferation}

Explant types employed for callus induction were leaf blade with midrib and petiole. The explants were prepared by excising it into $1 \mathrm{~cm}$ in diameter under aseptic manner using sterilized scalpels and inoculated on basal MS medium supplemented with 300mg/L PVP, $100 \mathrm{mg} / \mathrm{L}$ myo-inositol and $3 \%$ of sucrose and various concentrations of NAA $(1.0,2.0$ and 3.0mg/L), TDZ (0.5, 1.0 and $1.5 \mu \mathrm{M})$ and kinetin $0.5 \mathrm{mg} / \mathrm{L}$.

The cultures were kept in dark inside the culture room at $25 \pm 2{ }^{\circ} \mathrm{C}$ and humidity 55$65 \%$. The observations were recorded for callus induction (days), callus initiation (\%), callus texture and callus colour. There were three concentration used for each growth regulator with 10 replications in each treatment and the experiment was repeated three times.

\section{Statistical analysis}

Collected data was subjected to statistical analysis by SPSS (computer software package version 20.0). Analysis of variance was applied to test mean differences among all treatments followed by Turkey's-b multiple range test and represented as mean \pm SE. The value $\mathrm{p} \leq 0.05$ was considered statistically significant in each case.

\section{Results and Discussion}

In present investigation, different concentrations and combination of growth hormones had been optimized for rapid callus induction using leaf and petiole as explant in Carica papaya and presented in Table 1-2 and Figure 1-2. A significant $(p<0.05)$ difference in time span for callus induction was observed in different media combinations using leaf explants whereas time span for callus induction in petiole explants did not differ significantly $(p>0.05)$.

The comparatively less time span as compared to other hormone combinations for callus induction was found to be in media containing $3.0 \mathrm{mg} / \mathrm{L} \mathrm{NAA}+0.5 \mathrm{mg} / \mathrm{L} \mathrm{Kin}+1.0 \mu \mathrm{M}$ TDZ for both leaf and petiole. However a significantly similar $(p>0.05)$ time span was to be noted in two other hormone combinations i.e. MS media supplemented with $1.0 \mathrm{mg} / \mathrm{L} \mathrm{NAA}+0.5 \mathrm{mg} / \mathrm{L} \mathrm{Kin}+0.5 \mu \mathrm{M}$ TDZ and $2.0 \mathrm{mg} / \mathrm{L} \mathrm{NAA}+0.5 \mathrm{mg} / \mathrm{L} \mathrm{Kin}+1.0$ $\mu \mathrm{M}$ TDZ.

The other media combinations were found to significantly similar in $(p>0.05)$ for time span to induce callus. The findings of this study are in conformity with the results obtained by Fiegert et al., (2000); Jayasree et al., (2001) and Yasmin et al., (2003) whereas contrary results are reported by Prahardini and Sudaryono (1992) who observed best callus induction in midrib explant in seven days on MS media supplemented with combinations of BA and NAA. However, the basic salts utilized in the medium were same but the growth hormones and their concentrations were different. Thus it may be the result of different hormone combination. 
Table.1 Effect of different plant growth hormones on callus induction from leaf explants

\begin{tabular}{|c|c|c|c|c|c|}
\hline $\begin{array}{l}\text { S. } \\
\text { No. }\end{array}$ & Plant Growth Hormones & Time span & $\begin{array}{c}\% \text { Explant produced } \\
\text { callus }\end{array}$ & $\%$ cotton-fibre & Texture \\
\hline 1 & Basal MS + NAA (1.0) + Kin $(0.5)$ & $31.33 \pm 0.33^{d}$ & $11.33 \pm 0.88^{\mathrm{a}}$ & $0.00 \pm 0.00^{\mathrm{a}}$ & Soft \\
\hline 2 & Basal MS + NAA (2.0) + Kin $(0.5)$ & $29.00 \pm 1.52^{b c d}$ & $30.00 \pm 1.15^{\mathrm{c}}$ & $0.00 \pm 0.00^{\mathrm{a}}$ & Soft \\
\hline 3 & Basal MS + NAA (3.0) + Kin $(0.5)$ & $30.33 \pm 1.20^{\mathrm{cd}}$ & $21.00 \pm 0.57^{b}$ & $0.00 \pm 0.00^{\mathrm{a}}$ & Soft \\
\hline 4 & $\begin{array}{l}\text { Basal MS + NAA }(1.0)+\operatorname{Kin}(0.5)+\text { TDZ } \\
(0.5 \mu \mathrm{M})\end{array}$ & $25.66 \pm 0.33^{\mathrm{ab}}$ & $69.00 \pm 2.64^{\mathrm{d}}$ & $3.66 \pm 1.52^{b}$ & $\begin{array}{c}\text { Soft and } \\
\text { spongy }\end{array}$ \\
\hline 5 & $\begin{array}{l}\text { Basal MS + NAA }(2.0)+\text { Kin }(0.5)+\mathrm{TDZ} \\
(1.0 \mu \mathrm{M})\end{array}$ & $27.33 \pm 0.33^{\mathrm{abc}}$ & $78.33 \pm 0.88^{\mathrm{e}}$ & $6.66 \pm 2.51^{b}$ & $\begin{array}{l}\text { Soft and } \\
\text { spongy }\end{array}$ \\
\hline 6 & $\begin{array}{l}\text { Basal MS + NAA (3.0) + Kin }(0.5)+\mathrm{TDZ} \\
(1.5 \mu \mathrm{M})\end{array}$ & $25.00 \pm 0.57^{\mathrm{a}}$ & $90.00 \pm 0.57^{\mathrm{f}}$ & $10.66 \pm 1.52^{c}$ & $\begin{array}{c}\text { Soft and } \\
\text { spongy }\end{array}$ \\
\hline
\end{tabular}

Table.2 Effect of different plant growth hormones on callus induction from petiole explant

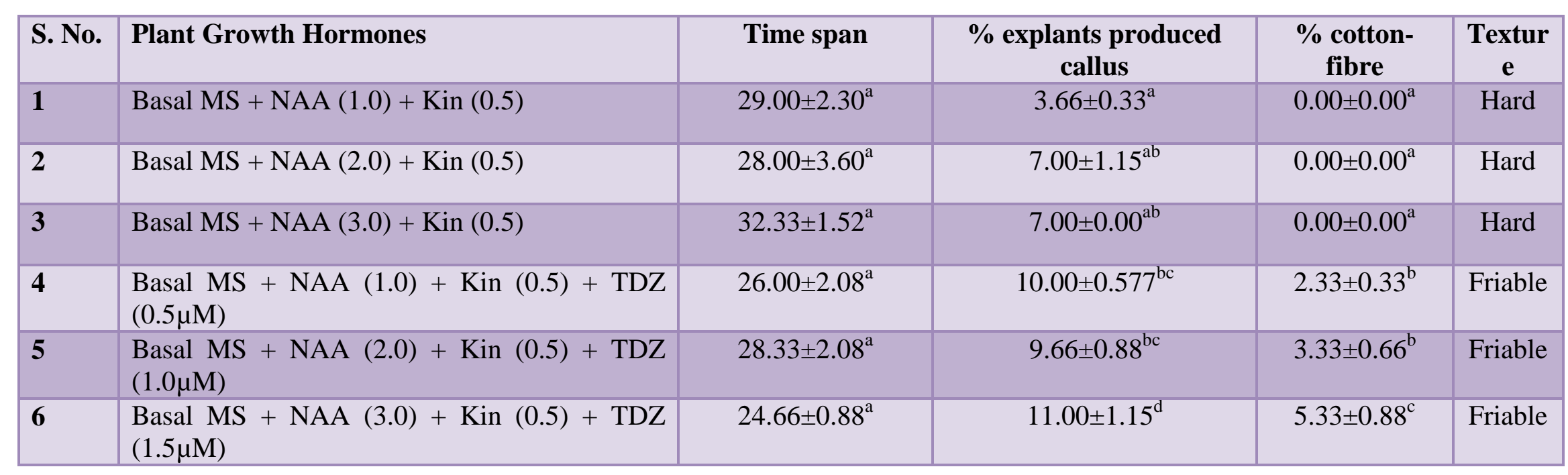


Int.J.Curr.Microbiol.App.Sci (2019) 8(7): 1217-1225

Fig.1 Callus produced from leaf explant

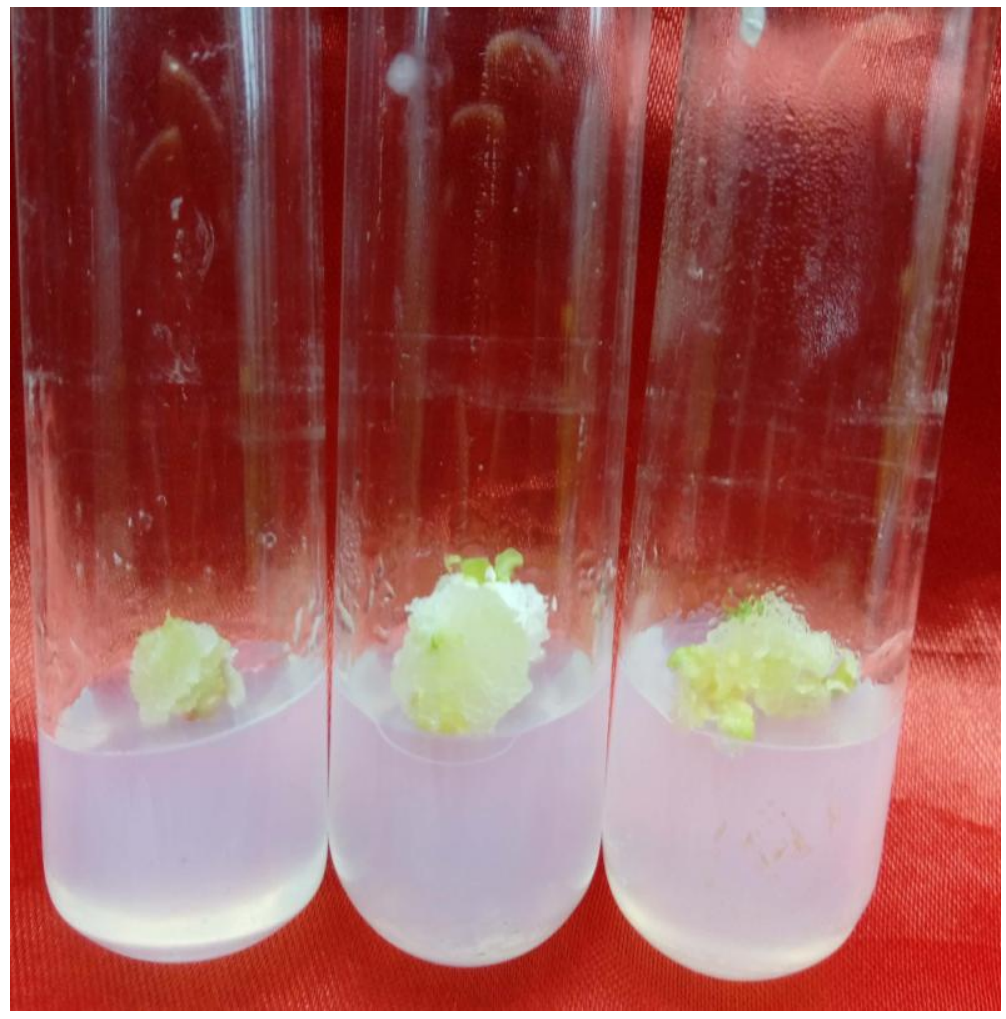

Fig.2 Callus produced from Petiole explant

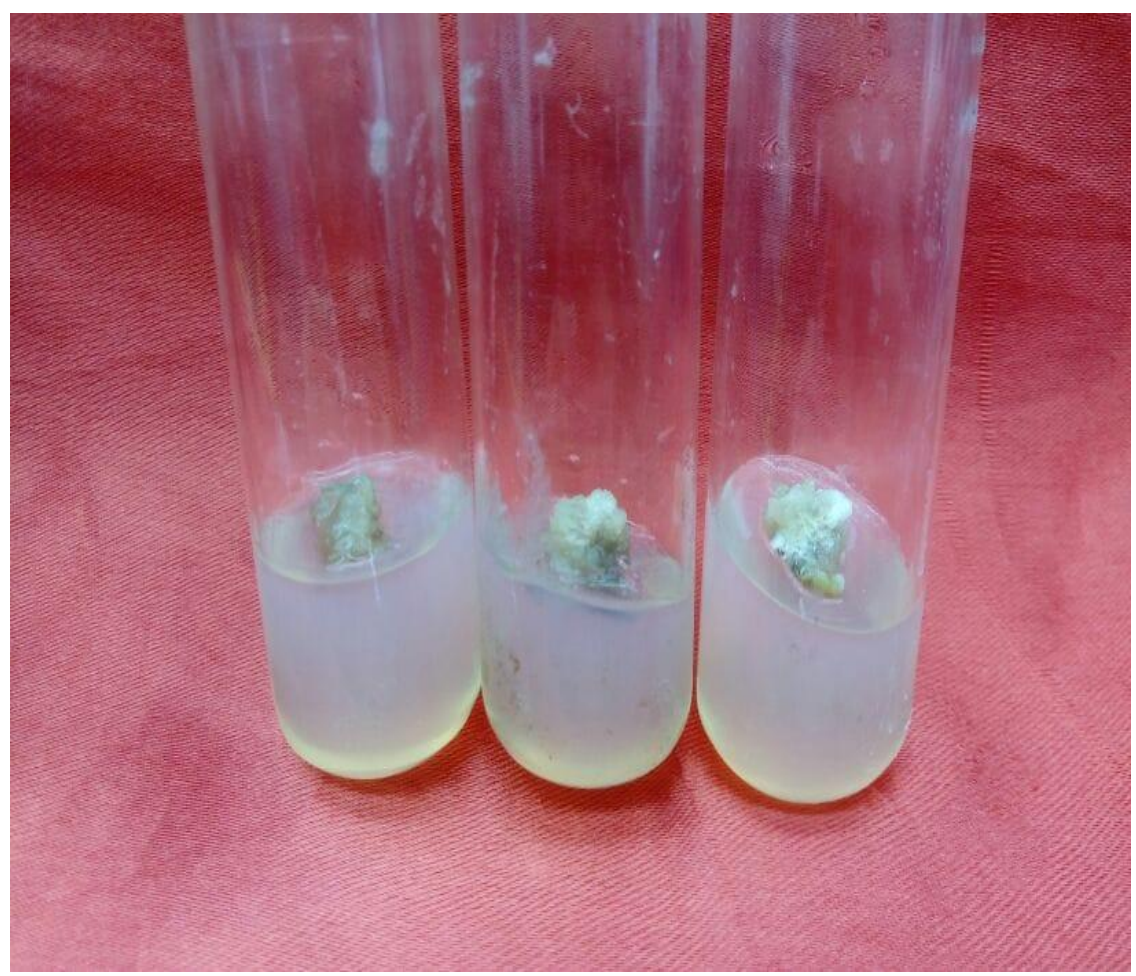


Fig.3 Appearance of cotton-fibre like substances formed on callus surface area

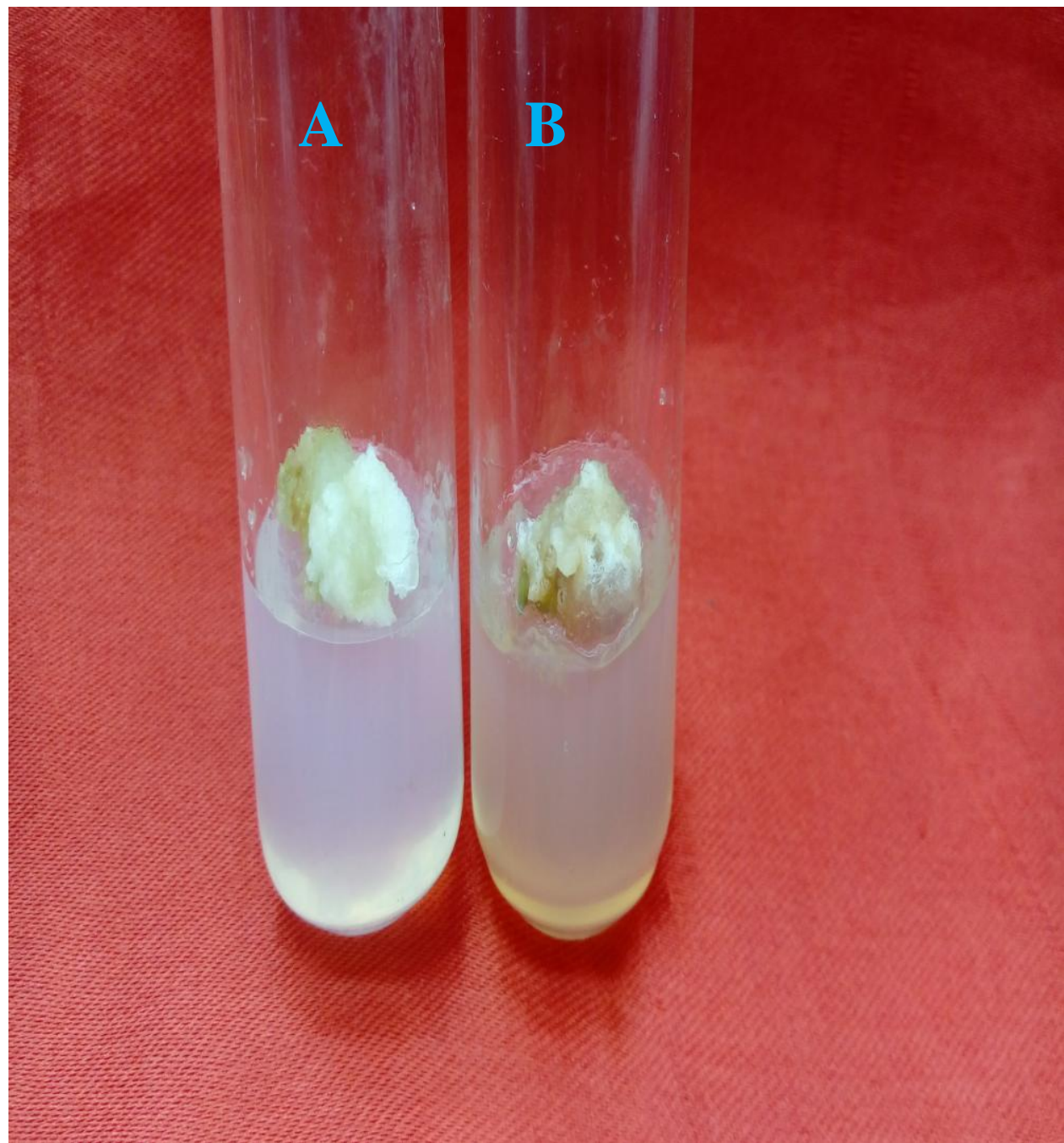

(A) Leaf callus

(B) Petiole callus

Under this study, the explants inoculated medium without any growth hormone did not produce any callus. Similar results are reported by Verma et al., (2016).

The more variation was to be noted in percent explants produced callus (Table 1). The significantly $(p<0.05)$ higher percent of explants was produced callus in media containing $3.0 \mathrm{mg} / \mathrm{L} \mathrm{NAA}+0.5 \mathrm{mg} / \mathrm{L} \mathrm{Kin} \mathrm{+}$ $1.5 \mu \mathrm{M}$ TDZ in comparison to other hormonal combinations in both petiole $(11 \%)$ and leaf
(90\%) (Fig. 1 and 2). Malabadi et al., (2011) also reported TDZ (upto $2.27 \mu \mathrm{M}$ ) to be an effective growth regulator for callus induction while working on different varieties of Carica papaya. A similar trend was noted in significant $(p<0.05)$ increase of percent explant callus produced with the increase in NAA and TDZ concentration. The comparatively lowest percent of explants produced callus (petiole $3.66 \%$ and leaf $11.33 \%$ ) was shown to be in media containing only $1.0 \mathrm{mg} / \mathrm{L}$ of NAA and $0.5 \mathrm{mg} / \mathrm{L}$ Kin. A 
significant $(p<0.05)$ increase in formation of cotton-fibre like substance was also observed with the increase in concentration of TDZ in both leaf and petiole (Table 1 and 2; Fig. 3). However, media combinations without TDZ did not appear any cotton-fibre like substance. The callus produced through leaf was softy and spongy like texture whereas, petiole produced hard and friable callus texture.

Under study, leaf explants was almost completely converted into callus suggesting leaf with mid rib as the best explants for higher callus induction. The results obtained by leaf blade with midrib explants are in accordance with the findings reported by Prahardini and Sudaryono (1992). Panjaitan et al., (2007) also reported that the highest amount of callus (90\%) was obtained in treatment containing $0.20 \mathrm{mg} / \mathrm{L} \mathrm{NAA}$ without BAP. Earlier researchers reported that auxin was critical for initiation and subsequent growth of callus. Out of three auxins investigated viz., NAA was found to be most effective followed by 2,4-D and IAA (Arora and Singh 1978; Teixeria da silva et al., 2007). They also stated that addition of 1.0 mg/L NAA was enough for good callus growth. Cytokinins at low concentrations, in combination with auxins were often used in plant species to promote callus initiation (Chai and Mariam, 1998). The application of TDZ and NAA in combination was used successfully to induced callus and somatic embryogenesis in the five Turkish crocus species (Verma et al., 2016).

The obtained callus was transferred to proliferation media containing NAA (1.0 $\mathrm{mg} / \mathrm{L}, \quad 2.0 \mathrm{mg} / \mathrm{L}$ and $3.0 \mathrm{mg} / \mathrm{L}$ ). Callus obtained from leaf explants was observed maximum proliferation at MS medium containing $2.0 \mathrm{mg} / \mathrm{L}$ NAA whereas petiole showed higher proliferation at $3.0 \mathrm{mg} / \mathrm{L}$ NAA. However, callus proliferation rate for both explants were found to be significantly
( $p>0.05)$ similar in media supplemented with $3.0 \mathrm{mg} / \mathrm{L}$ NAA. The results obtained under study are supported by the study of Usman et al., (2002).

The Study reported that increase in TDZ concentration resulted in early and maximum callus induction thus incorporation of TDZ with NAA as an efficient hormone combination for good quality callus induction and leaf as the best explants for rapid and higher percent of callus production.

\section{References}

Arora, I.K. and Singh, R.N. 1978. Growth hormones and in vitro callus formation of papaya. Sci. Hort. 8: 355-361.

Bhattacharya, J. and Khuspe, S.S. 2001. In vitro and in vivo germination of papaya (Carica papaya L.) seeds. Sci. Hortic. 91: 39-49.

Chai, B.L. and Mariam, B.S. 1998. Application of biotechnology in turf grass genetic improvement. Crop Sci. 38: 1320-1338.

FAOSTAT 2017. Food and agriculture organisation for the United Nations Statistics online database. Available from http://faostat.fao.org.

Fernando, J.A., Melo, M. and Soares, M.K.M. 2001. Anatomy of somatic embryogenesis in Carica papaya L. Braz. Arch. Biol. Technol. 44: 247-255.

Fiegert, A.K., Mix, W.G., Vorlop, K.D. 2000. Regeneration of Solanum tuberosum L. Tomensa cv, Induction of somatic embryogenesis in liquid culture for the production of artificial seed. Landbauforschung Volkenrode.50: 199202.

Jaime, A., Silva, T.D., Rashid, Z., Nhut, D.T., Sivakumar, D., Gera, A., Souza, M.T. and Tennant, P.F. 2007. Papaya (Carica papaya L.) Biology and Biotechnology, 
Tree and forestry Sci. Biotech. 1(1): 4773.

Jayasree, T., Pavan, U., Ramesh, M., Rao, A.V., Reddy, K.J.M., Sadanandam, A. 2001. Somatic embryogenesis from leaf culture of potato. Plant Cell Tissue Organ Cult. 64: 13-17.

Jean, J., Soucy, J. and Pouliot, R. 2011. Effects of retinoic acid on keratinocyte proliferation and differentiation in a psoriatic skin model. Tissue Eng Part A. 17: 1859-1868.

Jordan, M. and Velozo, J. 1995. Improvement of somatic embryogenesis in highlandpapaya cell suspensions. Plant Cell Tissue and Organ Culture. 44: 189-94.

Malabadi, R.B., Vijaykumar, S., Mulgund, G.S., Nataraja, K. 2011. Induction of somatic embryogenesis in papaya (Carica papaya). Res. Biotechnol. 2(5): 40-55.

Ming, R., Moore, P.H., Zee, F., Abbey, C.A., Ma, H., Paterson, A.H. 2001. Construction and characterization of a papaya BAC library as a foundation for molecular dissection of a tree-fruit genome. Theor Appl Genet. 102: 892899.

Mondal, M., Gupta, S. and Mukherjee, B.B. 1994. Callus culture and plant production in Carica papaya L. (var. Honey Dew). Plant Cell Reports. 13: 390-93.

Mosella, C.L. and Iligaray, A.R. 1985. In vitro tissue culture as a tool for plant research and propagation. III. Responces of pawpaw (Carica pubescens, Lenne et Koch) to in vitro culture. Simiente. 55: 63-67.

Murashige, T. and Skoog, F. 1962. A revised medium for rapid growth and bioassays with tobacco tissue cultures. Physiol. Plant. 15: 473-97.

Pandey, R.M. and Rajeevan, M.S. 1983. Callus initiation and regeneration in tissue culture of papaya. In: Proc. Int.
Symp. Plant Cell Culture in Crop Improvement, Calcutta, India. pp. 6-10.

Panjaitan, S.B., Aziz, M.A., Rashid, A.A. and Saleh, N.M. 2007. In-Vitro Plantlet Regeneration from Shoot Tip of Fieldgrown Hermaphrodite Papaya (Carica papaya L. cv. Eksotika). Int. J. Agri. Biolo. 6: 827-832.

Prahardini, P.E.R. and Sudaryono, T. 1992. The effect of additional naphthalene acetic acid and benzyl adenine to the growth of papaya cv. Dampit using MS in vitro culture. J. Hortikultura. 2: 6-12.

Rajeevan, M.S., Pandey, R.M. 1986. Lateral bud culture of papaya (Carica papaya L.) for clonal propagation. Plant Cell, Tissue and Organ Culture. 5: 181-188.

Rojas, V.D.R. and Kitto, S.L. 1991. Regeneration of babaco (C. pentagona) from ovular callus. J. Amer. Soc. Hort. Sci. 116: 747-52.

Saker, M.M., Bekheet, S.A., Taha, H.S. and Reda, A.A. 1999. In vitro propagation of papaya (Carica papaya L.). Science and Biotechnology. 1: 47-43.

Teixeira da Saliva, J.A., Rashid, Z., Nhut, D.T., Dharini, S., Abed, G., Manoel, T.S.J. and Paula, F.T. 2007. Papaya (Carica papaya L.) biology and biotechnology. Tree and Forestry Sci. 1(1): 47-73.

Tsai, S.F., Yeh, S.D., Chan, C.F. and Liaw, S.I. 2000. High-efficiency vitrification protocols for cryopreservation of in vitro grown shoot tips of transgenic papaya lines. Plant Cell, Tissue and Organ Culture. 98: 157-164.

Usman, M., Fatima, B.M., Jaskani, J. and Muhammad, A.I. 2002. Development of a callogenic protocol in papaya (Carica papaya 1.). Int. J. Agri. Biol. 4: 99-102.

Veerannale, L. (1984). Seasonal Rytham on the Sex Expression of Papaya. In: Proc. Natl., Seminar Papaya and Papain Production. Tamil Nadu Agric. Univ. 
Coimbatore, Madras, March 26-27, pp.1-3.

Verma S.K., Das A.K., Cingoz G.S. and Uslu E. 2016. Influence of nutrient media on callus induction, somatic embryogenesis and plant regeneration in selected Turkish crocus species. Biotechnology Reports. 10: 66-74.

Vij, T. and Prashar, Y. 2015. A review on medicinal properties of Carica papaya Linn. Asian Pac. J. Trop. Dis., 5(1): 16.

Yang, J.S. and Ye, C.A. 1992. Plant regeneration from petioles of in vitro regenerated papaya (Carica papaya L.) shoots. Botanical Bull. Acad. Sinica. 33: 375-81.

Yasmin, S., Nasiruddin, K.M., Begum, R., Talukder, S.K. 2003. Regeneration and establishment of potato plantlets through callus formation with BAP and NAA. Asian J. Plant Sci. 2(12): 936940.

Ye, K.N., Yu, D.Q. Huang, J.C. and Li, B.J. 1993. Effect of desiccation on papaya somatic embryo storage and regeneration. Acta Scientiarum Naturalium Universitatis Sunyatseni., 32: 63-9.

\section{How to cite this article:}

Nisha Malik, Rakesh Singh Sengar, Manoj Kumar Yadav, Shiv Kumar Singh, Gopal Singh and Mukesh Kumar. 2019. Effect of Different Plant Growth Regulators on In-vitro Callus Induction in Carica papaya (cv. Pusa Nanha). Int.J.Curr.Microbiol.App.Sci. 8(07): 1217-1225.

doi: https://doi.org/10.20546/ijcmas.2019.807.145 